\title{
National and Corresponding Members
}

\section{National Members}

Argentina
Australia
Austria
Belgium
Bosnia \&
and Herzegovina
Brazil
Canada
China
Croatia
Cuba
Czech Republic
Denmark
Finland
France
Grangand
Hong Kong
Iran
Grand
Hoce

\begin{tabular}{|c|c|}
\hline \multirow{3}{*}{$\begin{array}{l}\text { Argentine Association of Medical Informatics } \\
\text { Health Informatics Society of Australia Ltd. } \\
\text { (HISA) }\end{array}$} & Italy \\
\hline & Japan \\
\hline & Kazakstan \\
\hline Working Group Medical Informatics of the & \\
\hline $\begin{array}{l}\text { Austrian Society for Biomedical Enginerring } \\
\text { (ÖGBMT) and of the Austrian Computer }\end{array}$ & Korea \\
\hline Society (AKMI) & Malaysia \\
\hline Belgian Medical Informatics Association & \\
\hline $\begin{array}{l}\text { Society for Medical Informatics of Bosnia } \\
\text { Herzegovina }\end{array}$ & Mali \\
\hline Brazilian Society of Health Informatics & The Netherlands \\
\hline COACH: Canada's Health Informatics & New Zealand \\
\hline Association & Norway \\
\hline China Medical Informatics Association & Philippines \\
\hline Croation Society for Medical Informatics & Poland \\
\hline Cuban Society of Medical Informatics & Romania \\
\hline $\begin{array}{l}\text { Czech Society for Biomedical Engineering } \\
\text { and Medical Informatics }\end{array}$ & Singapore \\
\hline The Danish Society for Medical Informatics & Slovak Republic \\
\hline Finnish Social and Health Informatics & \\
\hline Association (FinnSHIA) & Slovenia \\
\hline $\begin{array}{l}\text { French Medical Informatics Association } \\
\text { (AIM) }\end{array}$ & South A \\
\hline German Association for Medical Informatics, & Spain \\
\hline Biometry and Epidemiology & Sweden \\
\hline Greek Health Informatics Association & Switzerland \\
\hline $\begin{array}{l}\text { Hong Kong Society of Medical Informatics } \\
\text { John von Neumann Computer Society }\end{array}$ & Turkey \\
\hline Iranian Medical Informatics Association & United Kingdom \\
\hline Healthcare Informatics Society of Ireland & \\
\hline The Israeli Association for Medical & Uruguay \\
\hline Informatics (ILAM) & USA \\
\hline
\end{tabular}

Argentine Association of Medical Informatics Health Informatics Society of Australia Ltd. Working Group Medical Informatics of the Austrian Society for Biomedical Enginerring computer Belgian Medical Informatics Association Society for Medical Informatics of Bosnia $\mathrm{COACH}$ : Canada's Health Informatics Association Croation Society for Medical Informatics Cuban Society of Medical Informatics and Medical Informatics Finnish Social and Health Informatics French Medical Informatics Association German Association for Medical Informatics, Biometry and Epidemiology Hong Kong Society of Medical Informatics John von Neumann Computer Society Healthcare Informatics Society of Ireland Informatics (ILAM)
Italian Medical Informatics Society (AIIM) Japan Association for Medical Informatics Medical Pharmaceutical Information Association (MedPharmInfo)

Korea Society of Medical Informatics (KOSMI)

Malaysian Health Informatics Association (MHIA)

The Mali Society of Biomedical and Health Information (SOMBIS)

VMBI, Society for Healthcare Informatics Health Informatics New Zealand Norwegian Society for Medical Informatics Philippine Medical Informatics Society, Inc. Polish Society of Medical Informatics Romanian Society of Medical Informatics Association for Medical Bio-Informatics, Singapore (AMBIS)

Slovak Society of Biomedical Engineering and Medical Informatics

Slovene Medical Informatics Society (SIMIA)

South African Health Informatics Association Spanish Society of Health Informatics Swedish Federation for Medical Informatics Swiss Society for Medical Informatics Turkish Medical Informatics Association (TURKMIA)

British Computer Society Health Informatics Forum BCS HIF

Uruguay Society of Health Informatics American Medical Informatics Association

\section{Corresponding Members}

Albania, Algeria, Armenia, Azerbaijan, Bangladesh, Cameroon, Chile, Colombia, Egypt, India, Indonesia, Iraq, Kenya, Madagascar, Mexico, Moldova, Nigeria, Oman, Pakistan, Peru, Portugal, Russian Federation, Saudi Arabia, Syria, Tanzania, Uganda, United Arab Emirates, Venezuela, Zimbabwe

\section{Affiliate Members}

International Federation for Information Processing (IFIP) www.ifip.org/

International Federation of Health Records Organizations http://www.ifhro.org

World Health Organization

www.who.int 